\title{
Рудакова И.А., Бутенко Л.И. Система работы преподавателя русского языка как иностранного в условиях погружения в смыслообразующий контекст поликультурной среды
}

Интеграция мирового сообщества влияет на тенденции не только относительно содержательных компонентов учебного процесса, уровня сложности и темпа обучения, но и обусловливает потребность в мотивачионно-динамическом переосмыслении эффрективности обучения, катализируя поиск новых образовательных моделей и технологий, ориентированных на актуализацию потенциальноличностных резервов обучаемых. Для максимально эффективной реализачии модели построения процесса обучения в условиях погружения в смыслообразующий контекст поликультурной среды необходимо создание челостной системы работы преподавателя по обеспечению учебного прочесса в иноязычной среде.

Ключевые слова: интеграчия, модели и технологии обучения, поликультурная образовательная среда, смысловая сфера личности, смыслообразующий учебный контекст.

Система обеспечения процесса обучения в поликультурной среде имеет свою специфику.

В классической дидактике выделяются следующие этапы управления процессом обучения: планирование, организация, регулирование (стимулирование), контроль, оценка и анализ результатов. Следовательно, система работы преподавателя по обеспечению учебной адаптации иностранных учащихся в процессе обучения должна охватывать все перечисленные этапы. В соответствии с указанными этапами управления мы выделяем четыре направления деятельности преподавателя по созданию системы, обеспечивающей реализацию модели учебной адаптации личности иностранного студента: аналитическая деятельность, перспективное планирование деятельности, организационная деятельность по созданию программного, учебно-методического, дидактического, компьютерного, информационного, материально-технического обеспечения, мониторинг результатов реализации модели погружения в смыслообразующий контекст поликультурной среды.

Созданию системы по обеспечению учебного процесса на модели погружения в смыслообразующий контекст поликультурной среды предшествует работа преподавателя по анализу исходного уровня академической успешности, личностносмыслового и образно-эмоционального развития учащихся, а также состояния программного, учебно-методического, материально-технического, дидактического оснащения учебного процесса на предмет их соответствия возможностям реализации модели погружения в смыслообразующий контекст поликультурной среды студента-иностранца в процессе обучения в российском вузе [1]. 
Планирование деятельности преподавателя, прежде всего, должно получить оформление в разработке рабочих программ, в содержании которых будут отражены основные аспекты построения процесса обучения с учётом смыслообразующего контекста поликультурной среды российского вуза:

-постановка в пояснительной записке помимо академических целей и задач, целей и задач, направленных на личностно-смысловое развитие иностранных учащихся;

-определение направлений и этапов осуществления поставленных целей и задач;

-отбор содержания, определение форм и методов в календарно-тематическом планировании;

-использование форм контроля, позволяющих не только диагностировать знания, умения и навыки учащихся по предмету, но и отслеживать личностносмысловое и образно-эмоциональное развитие личности студента-иностранца по выделенным критериям.

Подобные моменты должны быть включены и в поурочные планы преподавателя. В целях реализации индивидуальных образовательных траекторий учащихся возможно создание индивидуальных программ по развитию их личностно-смысловой и образно-эмоциональной сфер.

Аналитическая деятельность преподавателя должна завершиться организационной работой по определению направлений обеспечения процесса обучения программным, учебно-методическим, материально-техническим, дидактическим комплексом.

\section{Деятельность преподавателя по созданию программного обеспечения}

В своей работе в области отбора содержания образования преподаватели могут использовать собственные модификации учебных программ по русскому языку как иностранному, обогащенные образно-эмоциональными элементами и способствующие развитию образно-эмоциональной и личностно-смысловой сфер учащихся. Данные учебные программы будут представлять собой творческие разработки педагогов, созданные для изучения русского языка как иностранного в различных его аспектах.

\section{Деятельность по созданию учебно-методического обеспечения}

Этот вид деятельности преподавателя предполагает адаптацию учебников нового поколения, учебных пособий, методических разработок в соответствии с целями и задачами личностно-смыслового развития личности студента; создание банка методических разработок уроков, систематизированных по различным темам учебного курса.

\section{Деятельность по созданию дидактического обеспечения}

Данная деятельность включает подготовку дидактического и раздаточного материала по темам к реализации модели построения процесса обучения на основе модели погружения в поликультурную среду вуза. Применение дидак- 
тических средств должно строго соответствовать целям, содержанию и логике предлагаемого материала, формам и методам его изучения. Следует выделить два направления работы преподавателя по созданию банка дидактических материалов:

-дидактическое обеспечение содержания, методов и форм изучения учебного материала;

-дидактическое обеспечение контроля и оценки качества изученного материала.

В системе работы преподавателя по обеспечению содержания учебного процесса на образно-эмоциональной основе мы выделяем три аспекта, направленные на создание трех психолого-дидактических ситуаций: введение теоретических знаний; организация исследовательской деятельности учащихся; создание образноэмоциональной ситуации, способствующей личностно-смысловому развитию студента-иностранца [2].

Работа преподавателя по введению теоретических знаний предусматривает действия по разработке и накоплению схем, графиков, диаграмм, таблиц, рисунковсимволов.

Для организации исследовательской деятельности учащихся преподавателю необходимо создать банк проблемных задач, ролевых и игровых ситуаций; карточек с заданиями, вопросами к аудитории; высказываний современников и изучаемых исторических деятелей; бесед по предложенным вопросам для повторения; алгоритмов для анализа репродукций картин, отражающих изучаемые исторические события; исторических или литературных фактов, способствующих пониманию изучаемого периода и имеющих противоречивую оценку современников, историков, политических и государственных деятелей; текстов, параграфов документов, справочников и другой учебной, научной, публицистической и художественной литературы.

Деятельность по обеспечению создаваемых на уроке образно-эмоциональных ситуаций включает в себя действия по накоплению, разработке и систематизации различных дидактических средств, позволяющих эмоциональный образ сделать личностно значимым для учащихся. В содержании этой деятельности мы выделяем следующие направления.

1. Формирование банка наглядных исторических образов (иллюстрации, портреты исторических, государственных, политических и других деятелей, репродукции картин), погружающих обучаемых в атмосферу урока.

2. Создание «музыкальной копилки», позволяющей создавать музыкальные образы с помощью различных музыкальных произведений. Этот музыкальный материал должен быть расклассифицирован в соответствии со шкалой эмоциональных состояний, например Е.А.Зинченко, и систематизирован тематически.

3. Создание «художественной галереи», включающей в себя дидактический материал для создания художественные образов (образы скульптуры, живописи, архитектуры). 
4. Создание «цветового спектра» - набора разноцветных карточек, аппликаций, подцветок, цветомузыки. Реальное использование цвета в процессе обучения поможет созданию необходимого эмоционального состояния у учащихся и, соответственно, вхождению в новую иноязычную среду.

5. Создание «литературной гостиной»- банка литературных образов, литературных персонажей поэтических и прозаических произведений; эмоционально насыщенных драматургических зарисовок; ярких образных фрагментов, способствующих определенным эмоционально-психологическим установкам.

6. Создание банка эмоциональных пауз, создаваемых с помощью музыки, стихов, фотографий, видеоклипов.

7. Создание копилки учительского слова (крылатые выражения, пословицы, поговорки русского народа, эпитеты, метафоры, образные, выразительные примеры из реальной жизни).

8. Создание видеофонда - набор видеосюжетов, мультипликаций, кинофрагментов.

9. Создание банка эмоциональных образов на основе информационных технологий.

10. Создание банка образов-символов.

11. Создание фонда тематических фонограмм, магнитофонных записей, воспроизводящих голоса животных, шум ветра, моря, дождя и др .

12. Сбор предметов, вещей для стилизации интерьера, несущих смысловую нагрузку (предметы быта, костюмы, элементы декора и др.).

Работа преподавателя по созданию и систематизации дидактических материалов по указанным направлениям должна осуществляться с учетом этапов возрастной психологии [3].

Все указанные материалы также должны быть систематизированы согласно их целевому назначению: для лекций, семинаров, практических занятий, самостоятельной работы и т.д.

Деятельность по созданию компьютерного обеспечения модели построения процесса обучения включает в себя следующие направления работы:

-создание компьютерного банка информации по проблемам личностносмыслового и образно-эмоционального обучения;

-компьютерное обеспечение учебных курсов;

-применение информационных технологий в процессе обучения, использование возможностей Интернета, электронных энциклопедий и справочников, электронных таблиц, текстовых и графических редакторов, анимационных редакторов для реализации процесса обучения на образно-эмоциональной основе.

Новые информационные технологии позволяют преподавателю и учащимся создавать различные образы в виде графических изображений, анимированных рисунков, мультимедийных презентаций с ярким видеорядом (иллюстрациями, видеоклипами, звуком). Достоинством использования информационных техно- 
логий в процессе обучения на образно-эмоциональной основе является наличие широких возможностей (быстрота и динамичность в создании собственных изображений, редактирование текста, музыкального оформления, цветовой гаммы). Образы, реализованные, например, с помощью компьютерной анимации, вызовут сопереживание, сочувствие, облегчат понимание между педагогом и учениками. Преподаватель может использовать их в практических работах, для проведения лекций, семинаров, бесед и других формах обучения.

Деятельность по созданию информационного обеспечения предполагает:

-организацию различных форм межпредметного сотрудничества преподавателей по внедрению модели построения процесса обучения на основе погружения в смыслообразующий контекст поликультурной среды в учебном процессе;

-оформление результатов работы преподавателя по реализации модели построения процесса обучения на основе погружения в смыслообразующий контекст поликультурной среды (статьи, методические разработки уроков, рабочие программы учебных курсов) и освещение их в средствах массовой информации и в Интернете;

-участие преподавателей в поисково-творческой деятельности по разработке актуальных проблем личностно-смыслового развития учащихся;

-обмен опытом работы на семинарах и научно-практических конференциях.

Деятельность по созданию материально-технического обеспечения предполагает:

-модернизацию, оформление учебных кабинетов согласно целям и задачам модели построения процесса обучения на основе погружения в смыслообразующий контекст поликультурной среды;

-модернизацию технических средств аудиторного фонда: магнитофоны, музыкальные инструменты, теле- и радиоаппаратура, видеомагнитофоны, кинопроекторы, средств оргтехники: копировально-множительные средства, сканер, средства отображения информации (видео- и мультимедиапроекторы), слайдпроекторы и графопроекторы, жидкокристаллическая проекционная панель.

Мониторинг результатов реализации модели включает следующие направления работы преподавателя:

- разработка процедуры мониторинга;

- формирование диагностической базы мониторинга качества образования в условиях реализации модели построения процесса обучения на образноэмоциональной основе;

-мониторинг деятельности учащихся по критериям личностно-смыслового развития;

-мониторинг деятельности учащихся по критериям образно-эмоционального развития;

-изучение учебных достижений обучающихся (знаний, умений и навыков); 
- работа преподавателя по созданию «портфолио» («портфеля достижений») обучающихся. Целесообразным, на наш взгляд, является включение в содержание «портфолио» работ иностранных учащихся по созданию образов и преобразованию ими теоретического материала в образный и наоборот: оригинальные высказывания, «репортажи» о стране пребывания, о культуре России, о российских писателях и городах, о событиях, письма к политическим и государственным деятелям, схемы, плакаты, рисунки и т.п.

На современный момент в педагогической литературе существует много диагностирующих заданий, выявляющих не только уровень знаний, умений и навыков учащихся по учебному предмету, но и уровень развития тех или иных способностей обучаемого. Однако следует отметить, что диагностика качества образования в условиях реализации данной модели имеет, на наш взгляд, свою специфику, обусловленную критериями и уровнями образно-эмоционального и личностно-смыслового развития учащихся. Диагностические процедуры должны позволить выявить как уровень обученности и качества знаний студентов, так и уровень развития критериев их образно-эмоциональной и личностно-смысловой сфер. Дидактический материал, являющийся основой данной диагностики, должен отличаться креативностью, оригинальностью, быть обогащенным смысловыми, образно-эмоциональными элементами, способствовать раскрытию творческого потенциала личности студента-иностранца [5] .

Для диагностики личностно-смыслового и образно-эмоционального развития учащихся предлагается использовать различные виды творческих заданий, в результате которых происходит оценка не только учебных достижений по предмету (в частности русского языка), а оригинальности, креативности, развитости воображения, творческих способностей учащихся. Такие задания могут быть систематизированы согласно следующим критериям.

1. Преобразование теоретического материала в образный. Например:

-изобразите с помощью символических образов изученный материал (на примере материалов по научному стилю речи);

-подберите литературный образ (из прочитанных учебных текстов), передающий ваш характер, настроение.

-с помощью различных средств (музыкальных, художественных, литературных) выразите смысл изученного материала;

-напишите на русском языке сценарий фильма, спектакля, стихи, песню по определенной теме занятия;

-создайте собственный мультимедийный проект-презентацию по изученному материалу.

Преподаватель, предлагая ученикам подобные задания, предоставляет им полную свободу в выборе цвета, размера, материала, средств создания образов. Однако при оценке результатов педагог должен учитывать не только все перечисленные параметры, но и скорость выполнения задания, уровень абстрактности, оригинальности, креативности и адекватности выполненных образов содержанию 
преобразованного теоретического материала. Эти показатели свидетельствуют о степени развития образного мышления учащихся, об их эмоциональном состоянии и отношении к изучаемому материалу, выражает значимость изученного для школьников.

\section{2. Преобразование смыслообразующего материала в теоретический.} Например:

-проанализируйте, установите причинно-следственные связи и сделайте теоретические выводы на основе данного отрывка (приводится яркий фрагмент художественного текста);

-проанализируйте репродукции двух картин (отечественный и зарубежный художники), объясните, что объединяет их;

-объясните смысл данной метафоры (крылатого выражения, эпитета, фразеологического оборота) в применении к изучаемой теме;

-на примере прослушанной песни, репродукции картины выявите сущность данной эпохи, определите исторические образы, стоящие за символами этих произведений, объясните причины рождения данного произведения в этот период, что оно символизирует, какие эмоции владеют данным героем или автором произведения.

В спектр параметров оценки данных творческих заданий, помимо традиционных, включены такие, как аналогичность, ассоциативность, дивергентность мышления, что также будет свидетельствовать об уровне образно-эмоционального развития учащихся, и как следствие о развитии их личностно-смысловой сферы.

\section{3. Представление теоретического материала в образно-эмоциональном} контексте. Например:

-при изучении темы учащимся предлагается войти в образ литературного героя, исторического, политического, государственного деятеля и составить соответствующую речь, обращенную к нему;

-напишите репортаж (после посещения музея, выставки, театра, экскурсии по городу, просмотра фильма, встречи с интересным человеком);

-напишите письмо российскому правительству, выразив свои мысли и чувства по поводу осуществляемого им внешнеполитического курса;

- напишите ответ от имени исторического, политического или государственного деятеля на письма к нему оппозиционно настроенных лидеров, ученых, писателей, художников и т.п. с изложением причин своего выбора исторического пути России;

-напишите письмо к предполагаемому лидеру любого направления общественного движения с выражением восхищения или неприятия его идей и действий.

Суммарная оценка данных текстов, созданных учащимися, складывается из оценок уровня эмоциональности, образности, аргументированности ими своих идей, нестандартности, изобретательности, выдумки, самостоятельности и независимости суждений, являющиеся проявлениями творческого мышления. А высокий уровень эмпатии, отраженный в данных сочинениях раскроет личную значимость 
для иностранных учащихся изученного материала, понимание и осмысление явлений данной поликультурной среды.

Анализ экспериментальных данных показывает, что в большей степени реализация модели построения процесса обучения будет зависеть от целенаправленной деятельности преподавателя по организации эффективной системы обеспечения учебного процесса программными, учебно-методическими, дидактическими материалами и материально-техническими средствами, по разработке процедуры мониторинга и создании его диагностической базы с целью отслеживания динамики личностно-смыслового развития учащихся [4].

Анализ полученных результатов и последствий практической реализации модели построения процесса обучения на модели погружения в смыслообразующий контекст поликультурной среды российского вуза в целом подтвердили эффективность использования заявленной модели в процессе обучения.

\section{Литература}

1. Абакумова И.В. Обучение и смысл: смыслообразование в учебном процессе. (Психолого-дидактический подход). Ростов-на-Дону: Изд-во Рост. ун-та, 2003. 480 с.

2. Зинченко В.П.. Мунипов В.М., Гордон В.М. Исследование визуального мышления // Вопросы психологии. 1973. № 2. С. 3-14.

3. Лизинский В.М. Приемы и формы учебной деятельности. М.: Педагогический поиск, 2002. 160 с.

4. Личностно-ориентированный подход в работе педагога: разработка и использование / Под ред.Е.Н. Степанова. М.: ТЦ Сфера, 2006. 128 с.

5. Митина Л.М., Асмаковец Е.С. Эмоциональная гибкость учителя: психологическое содержание, диагностика, коррекция. М.: Московский психолого-социальный институт: Флинта, 2001. 192 с. 
Roudakova I.A., Boutenko L.I.

\section{The system of work of the Russian language teacher teaching Russian as a foreign language in the conditions of the immersion into sense forming multicultural environment}

The integration of world society doesn't only influence the content of educational process, but the level of the difficulty and the progress rate, it causes the necessity of motive-dynamic assessment of the educational efficiency, catalyzing the search for the new educational models and technologies, oriented to the actualization of potential and personal reserves of the students. It is necessary to create the unique system of teacher's work ensuring educational process in foreign environment if we want to realize the most effective model of teaching process building in the conditions of the immersion into sense forming multicultural environment.

Key words: integration, models and technologies of teaching, multicultural educational environment, sense sphere of the personality, sense forming educational context.

The system of ensuring educational process in multicultural environment has some particularities.

In the classical didactics they distinguish the following stages of teaching process management: planning, organization, regulation (stimulation), control, assessment and result analysis. So, the system of the teacher's work, ensuring the educational adaptation of foreign students, must include the above-mentioned stages. According to these stages of management, we separate four directions of teacher's activity in order to create the system, ensuring the educational adaptation of personality of the foreign student: analytical activity, perspective planning activity, organizational activity: making teaching aids, creating program, didactic, computer, information, material and technical support, monitoring of the results of the immersion into sense forming context of multicultural environment.

Before creating educational kit which will support educational process using the models of the immersion into sense forming context of multicultural environment, the teacher should concentrate upon analysis of the initial academical success, personality-oriented, visual and emotional development of the student, and the present state of program, didactic, computer, information, material and technical support in order to check their accordance with models of the immersion into sense forming context of multicultural environment of foreign student in the process of education in Russian Institution of Higher Education [1].

Planning of teacher's activity, first of all, must receive implementation in the curriculum writing, where will be reflected the main aspects of educational process 


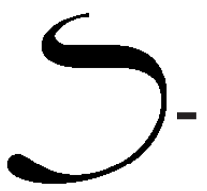

building taking into consideration sense forming context of the multicultural sphere of Russian Institution of Higher Education:

- Description in memorandum apart from academical goals and tasks, those oriented to personal sense development of the foreign students;

- Choice of the directions and stages to achieve goals and tasks in hand;

- Choice of content, definition of forms and methods in lesson planning;

- Apllication of such forms of control which doesn't only let to check knowledge, skills and abilities of the students, but follow personal sense forming and visualemotional development of the foreign student according to determined criteria.

Such points must be included into teacher's lesson plans. It's possible to create individual programs of personal sense forming and visual-emotional development of the foreign students contributing to establish individual educational trajectories.

Teacher's analytical work must be concluded by the organizational work consisting in choosing program, didactic, computer, information, material and technical support in correspondence with created directions of educational process.

\section{Teacher's activity to create program support includes:}

We suggest that in the field of the content selection the teachers should use their own modifications of programs in Russian as a foreign language, enriched by visualemotional elements, which are ministerial to personal and sense forming development of the students. These educational programs will represent creative works of educators, made to illustrate different aspects of the studied material.

\section{Teacher's activity to create teaching aids:}

This kind of activity suggests the adaptation of the textbooks of new generation, teaching aids, methodics works in accordance with goals and tasks of the personal and sense forming development of the student; creation of the bank of the original lesson plans, systematized according to different themes of the course.

\section{Teacher's activity to create didactic support:}

This activity suggests preparation of the didactic material and hand-outs for the studied themes using the model of the immersion into sense-forming multicultural environment. The application of the didactic means should correspond to goals, content, logic of the suggested material, forms and methods of the learning. We should point out two directions to create the bank of the didactic materials:

- Didactic support of the content, methods and forms of the studied class material;

- Didactic support of the monitoring of the results and quality control of the studied material.

In the system of the teacher's work ensuring the content of educational process at visual and emotional basis they distinguish three aspects, destined to construct three psychological and didactic situations: the introduction of the theoretical knowledge; research activity of the students; creation of the emotional situation, contributing to personal and sense forming development of the student- foreigner [2]. 
In order to provide good introduction of the theoretical knowledge the teacher should make and accumulate different schemes, graphics, diagrams, tables, and drawings-symbols.

To realize research activity the teacher should create problem tasks and role plays, challenges, cards with assignments, questions to the audience; contemporaries' considerations about historical figures; discussions based on proposed questions for revising the material; algorithms for analysis of picture reproductions, reflecting the historical events; historical or literature facts, helping to understand better the studied period and having controversial appraisal among contemporaries, historians, political and state leaders; texts, paragraphs of the documents, reference books and other educational, publicist, scientific, and artistic literature.

The activity providing visual and emotional situations involves accumulation, elaboration and systematization of different didactic means, which let to attach personal sense to visuality. In the content of this activity we can underline the following tendencies:

1. Creation of the of visual historical characters (illustrations, historical portraits, the portraits of the state, political and other leaders, reproductions of the pictures), plunging students into the lesson atmosphere.

2. Creation of «music box» with different musical masterpieces. This musical material should be classified according to the scale of emotional states, for instance E.A.Zinchenko, and systemized thematically.

3. Creation of "art gallery", including didactic material permitting to create artistic types (the pictures of sculptures, painting, architecture);

4. Creation of «color spectrum» - a set of multicolored cards, applications, shading colours, color music. The use of the color in the educational process can create the necessary emotional state among students, and correspondingly, his immersion into foreign environment.

5. Creation of «literary reception room» - the bank of literary characters, literary figures of poetic masterpieces; rich in emotions dramatic extracts; bright visual sketches, permitting to make certain emotional and psychological attitudes.

6. Creation of emotional pauses, made with the help of music, poetry, photos, video clips.

7. Creation of teacher's eloquent expressions (idioms, proverbs, proverbial phrase of Russian people, epithets, metaphors, visual, expressive examples of the real life).

8. Creation of video fund - a set of video subjects, cartoons, film extracts.

9. Creation of the bank of the emotional representations at multimedia basis.

10. Creation of the bank of characters- symbols.

11. Creation of the thematic recordings, tape recordings, reproducing animal voices, the sounds of the wind, sea, rain and etc .

12. Selection of objects, things for interior styling, conveying different meanings (amenities, costumes, elements of decorations and etc). 


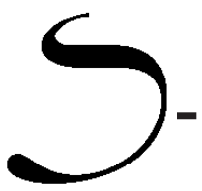

Teacher's work directed to systematization of didactic materials according to these directions must be carried out taking into consideration age psychology [3].

All these materials should be systemized according to their use: for lectures, workshops, practical studies, original work and etc.

\section{Teacher's activity directed to create computer support includes the following types of work:}

- Creation of computer data basis related to personal, sense forming and visual and emotional education;

- Computer support of the course;

- Application of information technologies in educational process, use of Internet resources, electronic encyclopedia and reference book, electronic tables, text and graphics redactor, image redactor to introduce visual and emotional aspects into educational processes.

New information technologies let to the teacher and the student to create different images in the form of graphics, cartons, multimedia presentations with bright illustrations(video clips and sound). New information technologies advantages are programmed in wide possibilities that they offer (promptness and dynamics of image creation, text editing, music accompaniment, range of colours). Visual images, made, for example, with the help of computer animation tools, will stimulate сопереживание, сочувствие, облегчат mutual understanding between educators and students. The teacher can use them in his practical works, for his lectures, workshops, conversations and other forms of the education.

The activity destined to create computer support suggests:

- Application of different forms of intersubject collaboration of teachers while introducing the new model of educational process building in the conditions of the immersion into sense forming multicultural environment;

- Drawing of teacher's work results while introducing the new model of educational process building in the conditions of the immersion into sense forming multicultural environment (articles, new lesson plans, programs for the courses) and their presentation in mass media and Internet;

- teacher's participation in research and creative projects devoted to current sense forming development of the students;

- experience exchange at the workshops and scientific conferences.

Teacher's activity of ensuring material and technical support suggests:

- modernization, classroom decoration in correspondence with goals and tasks of the model of the educational process at the basis of immersion into sense forming context of multicultural environment;

- modernization of the technical equipment used in the classroom: tape recorders, musical instruments, tele- and radio gadgets, video players, film projector, office equipment: photocopying equipment, scanner, means of showing information (video - and multimedia projector), slide projector and graphic projector, liquidcrystalline projection panel. 


\section{Monitoring of the results includes the following directions of the teacher's work:}

- elaboration of monitoring procedure;

- creation of diagnostic basis of quality monitoring of education under the conditions of building the educational process upon visual and emotional basis;

- monitoring of students' activity according to criteria of sense forming experience;

- monitoring of students' activity according to criteria of emotional and visual development;

- examination of the academical achievements of the students (knowledge and skills );

- teacher's work with «portfolio» («achievement register») of the students. We consider sensible the introduction into "portfolio" of foreign students, the works creating visual images and reconstructing theoretical material into visual one and vice versa: original statements, «reports» about the country, Russian culture, Russian writers and cities, events, letters to political and state leaders, schemes, posters, drawings and etc.

At present in pedagogic literature we can find a lot of screening assignments, discovering not only the level of the skills in this particular subject, but the level of students' abilities development. However it is necessary to remember, that the diagnostics in this model of the education has his own particular features, determined by the criteria and levels of visual and emotional and personal and sense forming development of the students. Diagnostic procedures must discover the level of training standard and quality of knowledge, as well as the level of the development of their visual and emotional, personal and sense forming spheres. Didactic material is the basis of such diagnostics, it must differ in creativity, originality, it must be enriched by sense, visual and emotional elements, and contribute to revealing creative potential of the student- foreigner's personality [5] .

We propose to give different creative assignments, if we need to examine their personal and sense forming, visual and emotional development, so we do not only assess subject progress (particularly Russian language mastering), but originality, creativity, imagination development, students'creative abilities. Such assignments can be systemized according the following criteria:

1. Modify the theoretical material into visual one. For example:

- Show with the help of the symbolic figures studied material (at the example of the materials of the scientific speech style);

- Choose the literate character (from the studied texts), which is close to you by his temper or the mood.

- With the help of different means (musical, artistic, literate) express the meaning of the studied material;

- Write in Russian a typescript for the film, spectacle, or the poem or the song to illustrate a topic;

- Make a multimedia presentation using the studied material. 


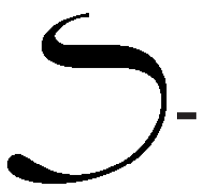

The teacher, giving to pupils such assignments, gives them absolute freedom in color, size, material, means choice, of images. However assessing the results, the teacher must take into consideration all the above-mentioned parameters, but the speed of assignment fulfillment, the level of originality, creativity, abstractiveness, correspondence of the created visual images to the content of the modified theoretical material. These indices speak about the degree of the students' visual thinking, their emotional state and relation towards the studied material, it shows the significance of the studied material for the students.

2. Modification of the sense forming material into theoretical one. For example:

- analyze, find out the cause-and-effect relations and make the theoretical conclusions after reading the extract (as an example they give an extract from the text);

- analyze the reproductions of two pictures (of national and foreign artists), explain what common traits exist;

- explain the meaning of this metaphor (winged words, epithet, idiom) in application to the studied theme;

case study : listen to the song or look at the picture reproduction and discover the features of the period, determine historical characters, staying behind the symbols of these works, explain the reasons of this work creation in this period, what it symbolizes, what emotions prevail in character's soul and what emotions the author of the book experience.

In the spectrum of the assessment of the creative works, apart from traditional points, there are divergence of the thinking, similarity, associativity, which will also testify about the level of visual and emotional development of the students and in consequence of their sense forming sphere development.

3. Presentation of the theoretical material in visual and emotional context. For example:

- while studying the subject, we suggest to the students to play the role of one of the literature characters, historical, political, state leaders and compose the appropriate speech, on behalf of this person;

- to write the report (about your visit to museum, exhibition, theatre, excursion around the town, the film you have seen, a meeting with an interesting person);

- to write a letter to Russian government, expressing ideas and feelings about its foreign policy;

- to write a reply on behalf of historical, political or state leader upon letters of the leaders, scientists, writes, painters and etc who are in opposition with their explanations about the choice of the historical way for Russia;

- to write a letter to probable leader of any direction of the social movement expressing admiration or denial of his ideas and actions.

The assessment of these texts, written by the students, is made from the assessments of the levels of emotionality, imagination, argumentativeness of their thoughts, unstandardized approach, ingenuity, invention, self-sufficiency and independence of 
thinking, which are exhibitions of creative mentality. The high level of the empathy will prove that the studied material is of great value, reflected in these compositions will reveal personal significance for foreign students of the studied material, understanding and apprehension of the phenomena of this multicultural environment.

The analysis of the experimental data show, that the introduction of the model of the educational process depends upon teacher's goal-oriented activity in a greater degree having the aim to organize the effective system of educational process support by making teaching aids, creating program, didactic, computer, information, material and technical support, monitoring of the results of the immersion into sense-forming context of multicultural environment [4].

The analysis of the received data and $u$ practical effects of the realization of the model of the educational process built upon the immersion into sense forming context of multicultural environment of Russian Institution of Higher Education in whole proved when applied the efficiency of this model.

\section{Literature}

1. Abakoumova I.V. Education and sense: sense forming in educational process. (Psychological-didactic approach). Rostov-on-Don: Rostov University publishing house, 2003. $480 \mathrm{p}$.

2. Zinchenko V.P., Mounipov V.M., Gordon V.M. Studies of visual thinking // The questions of psychology. 1973. № 2. P. 3-14.

3. Lizinskii V.M. The methods and forms of educational activity. M.: Pedagogical research, 2002. $160 \mathrm{p}$.

4. Personality-oriented approach in teacher's work: creation and development / Edited by E.N. Stepanova. M.: SC Sphere, 2006. 128 p.

5. Mitina L.M., Asmakovets E.S. Emotional teacher's flexibility: psychological content, diagnostics, correction. - M.: Moscow socio-psychological Institute :Phlinta, 2001. 192 p. 